\title{
Macrocyclic and Helical Oligoamides as a New Class of G- Quadruplex Ligands
}

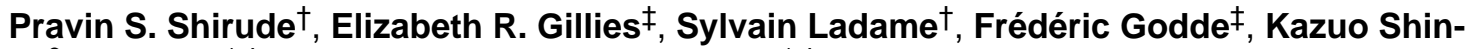 \\ $\mathrm{ya}^{\S}$, Ivan Huc ${ }^{*} \neq$, and Shankar Balasubramanian ${ }^{*}, \dagger$ \\ tUniversity Chemical Laboratory, University of Cambridge, Lensfield Road, Cambridge CB2 1EW, \\ U.K. \\ \#Institut Européen de Chimie et Biologie, Université Bordeaux 1-CNRS UMR 5248, 2 rue Robert \\ Escarpit, 33607 Pessac, France \\ $\S$ Chemical Biology Team Biological Information Research Center (BIRC), National Institute of \\ Advanced Industrial Science and Technology (AIST), Japan
}

\begin{abstract}
Nucleic acid sequences that comprise tandem guanine $(\mathrm{G})$ nucleotides are predisposed to forming four stranded structures called G-quadruplexes.1 It was recognized that the DNA sequences found at the telomeres could form G-quadruplexes in vitro.2 Recent studies have shown that natural proteins can promote quadruplex formation at the telomeres under the apparent control of a cell cycle dependent phosphorylation event, providing strong evidence for a functional role for telomeric DNA quadruplexes.3 Small molecules that selectively bind and stabilize the telomeric quadruplex can disrupt telomere function in cells 4 and are currently under investigation as potential anticancer agents.5 G-Quadruplex sequence motifs are prevalent in the genome 6 and are particularly enriched in gene promoters.7 This suggests that G-quadruplex formation may be linked to gene transcription, and that Gquadruplex stabilizing ligands may interfere with gene expression.8 A number of promoter quadruplexes associated with protooncogenes have been identified, which include c-myc, 8 c-kit,9 and Bcl-2.10 It has recently been suggested that G-quadruplexes in the $5^{\prime}$ untranslated regions of mRNAs modulate translation and may provide yet another class of targets for small molecule intervention. 11 There is thus considerable interest in the development of ligands that bind G-quadruplex sequence motifs. Herein, we report the tight and selective binding of cationic trimeric macrocycle $\mathbf{1}$ and helically folded tetramer $\mathbf{3}$ to quadruplex DNA (Figure 1).
\end{abstract}

Reported G-quadruplex ligands generally comprise a planar $\pi$-rich pharmacophore, presumed to bind to guanine tetrads, with appended side chains to enhance the binding interaction. 12 We reasoned that oligoamides of 8-amino-2-quinoline carboxylic acid might be good candidates for G-quadruplex binding owing to their ability to adopt very stable, planar, bent, or helically folded conformations in the solid state and in solution, 13,14 including in protic solvents. 15 Furthermore, their ability to penetrate cells, their resistance to protease degradation, and low toxicity make them attractive candidates for chemical biology and cell-based studies.16 Structural studies on lipophilic derivatives 14 support that dimer 2 would adopt a planar crescent-like conformation, that cyclic trimer $\mathbf{1}$ should also be planar, and that tetramer $\mathbf{3}$ should exist as racemic 1.5 turn helically folded conformers with

(C) 2007 American Chemical Society

E-mail: i.huc@iecb.u-bordeaux.fr; sb10031@cam.ac.uk.

Supporting Information Available: Details of the synthesis, characterization of new compounds, CD spectroscopic data. and Job plot. This material is available free of charge via the Internet at http://pubs.acs.org. 
aromatic but not rigorously flat faces. The cationic side chains in position 4 of each quinoline ring of structures $\mathbf{1}, \mathbf{2}$, and $\mathbf{3}$ confer water solubility and potential sites for chargecharge or hydrogen bonding interactions with DNA.

The ability of 1-3 to stabilize G-quadruplex DNA was investigated by FRET melting 17 analysis using the human telomeric G-quadruplex (h-telo) and also one of the c-kit promoter G-quadruplexes9b (c-kit), in comparison to a duplex DNA standard (dup). Telomestatin (4)18 is one of the strongest quadruplex ligands reported and was used as a reference for comparison. Table 1 and Figure 2 summarize the quadruplex melting data.

It was evident that 1 stabilized both the human telomeric and the c-kit G-quadruplexes even more strongly than the potent natural product telomestatin (4) and without any detectable stabilization of duplex DNA, indicative of quadruplex versus duplex selectivity. To our surprise, the helical tetramer $\mathbf{3}$ was also a moderately strong quadruplex stabilizing ligand with apparent selectivity relative to duplex DNA. The acyclic dimer $\mathbf{2}$ was, in contrast, a poor quadruplex ligand. We propose that macrocycle 1 recognizes the G-quadruplex via hydrophobic interactions with the terminal G-tetrad, as has been suggested for telomestatin. $18 \mathrm{~b}$ Ligand $\mathbf{3}$ is a novel class of G-quadruplex ligand which, owing to its three-dimensional helical structure, has the potential to interact with loops rather than primarily via the Gtetrad.

Circular dichroism (CD) spectroscopy was used to investigate whether new ligands $\mathbf{1}$ and $\mathbf{3}$ exhibit any selectivity for a particular G-quadruplex conformation. The $\mathrm{CD}$ spectrum (Supporting Information) of h-telo d $\left[\mathrm{A}\left(\mathrm{G}_{3} \mathrm{~T}_{2} \mathrm{~A}\right)_{3} \mathrm{G}_{3} \mathrm{~T}\right]$ in the absence of added salt shows a positive peak at $256 \mathrm{~nm}$. The addition of macrocycle 1 would appear to favor formation of the antiparallel structure, as judged by the emergence of a positive peak at $294 \mathrm{~nm}$. While we recognize the need to exercise caution in relying solely upon CD spectroscopy to assign quadruplex structure, it was interesting to note that telomestatin has been reported to induce a similar spectral change, under comparable conditions, 19 which supports our hypothesis that both 1 and telomestatin recognize the quadruplex via a similar binding mode. Furthermore, a Job analysis20 suggests that 1 binds to h-telo in a 2:1 stoichiometry (Supporting Information) which is comparable to the same analysis made for telomestatin.19 The CD spectra of h-telo plus macrocycle $\mathbf{1}$, in the presence of $100 \mathrm{mM} \mathrm{K}^{+}$or $\mathrm{Na}^{+}$, were consistent with an antiparallel G-quadruplex being the major conformation in the liganded complex (Supporting Information).

It was noteworthy that, when h-telo was titrated with helical oligomer 3, a CD band was observed at around $400 \mathrm{~nm}$ in the absorption region of the quinoline chromophore, suggesting that a preferred helical chirality was induced in $\mathbf{3}$ (Figure 3).21 Furthermore, the sign of this band depended on the presence or absence of added salt. In the presence of 100 $\mathrm{mM} \mathrm{K}^{+}$or $\mathrm{Na}^{+}$, a weak negative band appears corresponding to left handedness of $\mathbf{3}$ when it interacts with the salt-stabilized form of h-telo. On the contrary, in the absence of salt, a positive $\mathrm{CD}$ band appears corresponding to a right handedness of $\mathbf{3}$. These observations suggest that the recognition of quadruplexes by ligands such as $\mathbf{3}$ might be made more selective by imposing right or left handedness, for example, by using chiral residues.21

The addition of 3 to h-telo did not cause significant CD spectral changes in the $240-300 \mathrm{~nm}$ region, whether in the presence or in the absence of salt, suggesting that $\mathbf{3}$ does not induce a favored quadruplex conformation contrary to 1 . However, this interpretation must be subject to caution since $\mathrm{CD}$ bands belonging to $\mathbf{3}$ and h-telo overlap in this region.

The new ligands described here have shown significant potential for potent G-quadruplex stabilization without any evidence of duplex stabilization. The relative ease of synthesis of 
these molecules makes them amenable to chemical modification to improve affinity and tailor quadruplex selectivity. Progress along these lines will be reported in due course.

\section{Acknowledgments}

We thank the BBSRC, Cancer Research UK (for a program grant), and the European Commission (Marie Curie Postdoctoral Fellowship to E.R.G.) for funding. S.B. is a BBSRC Career Development Research Fellow.

\section{References}

1. Guschlbauer W, Chantot JF, Theile D. J. Biomol. Struct. Dyn. 1990; 8:491. [PubMed: 2100515]

2. Sen D, Gilbert W. Nature. 1990; 344:410. [PubMed: 2320109]

3. Paeschke K, Simonsson T, Postberg J, Rhodes D, Lipps HJ. Nat. Struct. Mol. Biol. 2005; 12:847. [PubMed: 16142245]

4. Gomez D, Paterski R, Lemarteleur T, Shin-ya K, Mergny JL, Riou JF. J. Biol. Chem. 2004; 279:41487. [PubMed: 15277522]

5. Cerone MA, Londono-Vallejo JA, Autexier C. Oncogene. 2006; 25:7411. [PubMed: 16767163]

6. (a) Huppert J, Balasubramanian S. Nucleic Acids Res. 2005; 33:2908. [PubMed: 15914667] (b) Todd AK, Johnston M, Neidle S. Nucleic Acids Res. 2005; 33:2901. [PubMed: 15914666]

7. Huppert J, Balasubramanian S. Nucleic Acids Res. 2007; 35:406. [PubMed: 17169996]

8. Siddiqui-Jain A, Grand CL, Bearss D, Hurley LH. Proc. Natl. Acad. Sci. U.S.A. 2002; 99:11593. [PubMed: 12195017]

9. (a) Rankin S, Reszka AP, Huppert J, Zloh M, Parkinson GN, Todd AK, Ladame S, Balasubramanian S, Neidle S. J. Am. Chem. Soc. 2005; 127:10584. [PubMed: 16045346] (b) Fernando H, Reszka AP, Huppert J, Ladame S, Rankin S, Venkitaraman AR, Neidle S, Balasubramanian S. Biochemistry. 2006; 45:7854. [PubMed: 16784237]

10. Dai J, Dexheimer TS, Chen D, Carver M, Ambrus A, Jones RA, Yang D. J. Am. Chem. Soc. 2006; 128:1096. [PubMed: 16433524]

11. Kumari S, Bugaut A, Huppert J, Balasubramanian S. Nat. Chem. Biol. 2007; 4:218. [PubMed: 17322877]

12. For example see: Jantos K, Rodriguez R, Ladame S, Shirude PS, Balasubramanian S. J. Am. Chem. Soc. 2006; 128:13662. [PubMed: 17044674] Dixon IM, Lopez F, Estève J-P, Tejera AM, Blasco MA, Pratviel G, Meunier B. ChemBioChem. 2005; 6:123. [PubMed: 15551357] Seenisamy J, Bashyan S, Gokhale V, Vankayalapati H, Sun D, Siddiqui-Jain A, Steiner AN, Shin-ya K, White E, Wilson WD, Hurley LH. J. Am. Chem. Soc. 2005; 127:2944. [PubMed: 15740131]

13. (a) Jiang H, Léger J-M, Huc I. J. Am. Chem. Soc. 2003; 125:3448. [PubMed: 12643704] (b) Jiang H, Léger J-M, Dolain C, Guionneau P, Huc I. Tetrahedron. 2003; 59:8365.

14. Jiang H, Léger J-M, Guionneau P, Huc I. Org. Lett. 2004; 6:2985. [PubMed: 15330664]

15. Gillies ER, Dolain C, Léger J-M, Huc I. J. Org. Chem. 2006; 71:7931. [PubMed: 17025279]

16. Gillies ER, Deiss F, Staedel C, Schmitter J-M, Huc I. Angew. Chem., Int. Ed. 2007; 46:4081. [PubMed: 17444578]

17. Mergny J-L, Maurizot J-C. ChemBioChem. 2001; 2:124. [PubMed: 11828436]

18. (a) Shin-ya K, Wierzba K, Matsuo K, Ohtani T, Yamada Y, Furihata K, Hayakawa Y, Seto H. J. Am. Chem. Soc. 2001; 123:1262. [PubMed: 11456694] (b) Kim M-Y, Vankayalapati H, Shin-ya K, Wierzba K, Hurley LH. J. Am. Chem. Soc. 2002; 124:2098. [PubMed: 11878947]

19. Rezler EM, Seenisamy J, Bashyam S, Kim M-Y, White E, Wilson WD, Hurley LH. J. Am. Chem. Soc. 2005; 127:9439. [PubMed: 15984871]

20. Job P. Ann. Chim. 1928; 9:113.

21. (a) Jiang H, Dolain C, Léger J-M, Gornitzka H, Huc I. J. Am. Chem. Soc. 2004; 126:1034. [PubMed: 14746467] (b) Dolain C, Jiang H, Léger J-M, Guionneau P, Huc I. J. Am. Chem. Soc. 2005; 127:12943. [PubMed: 16159288] 

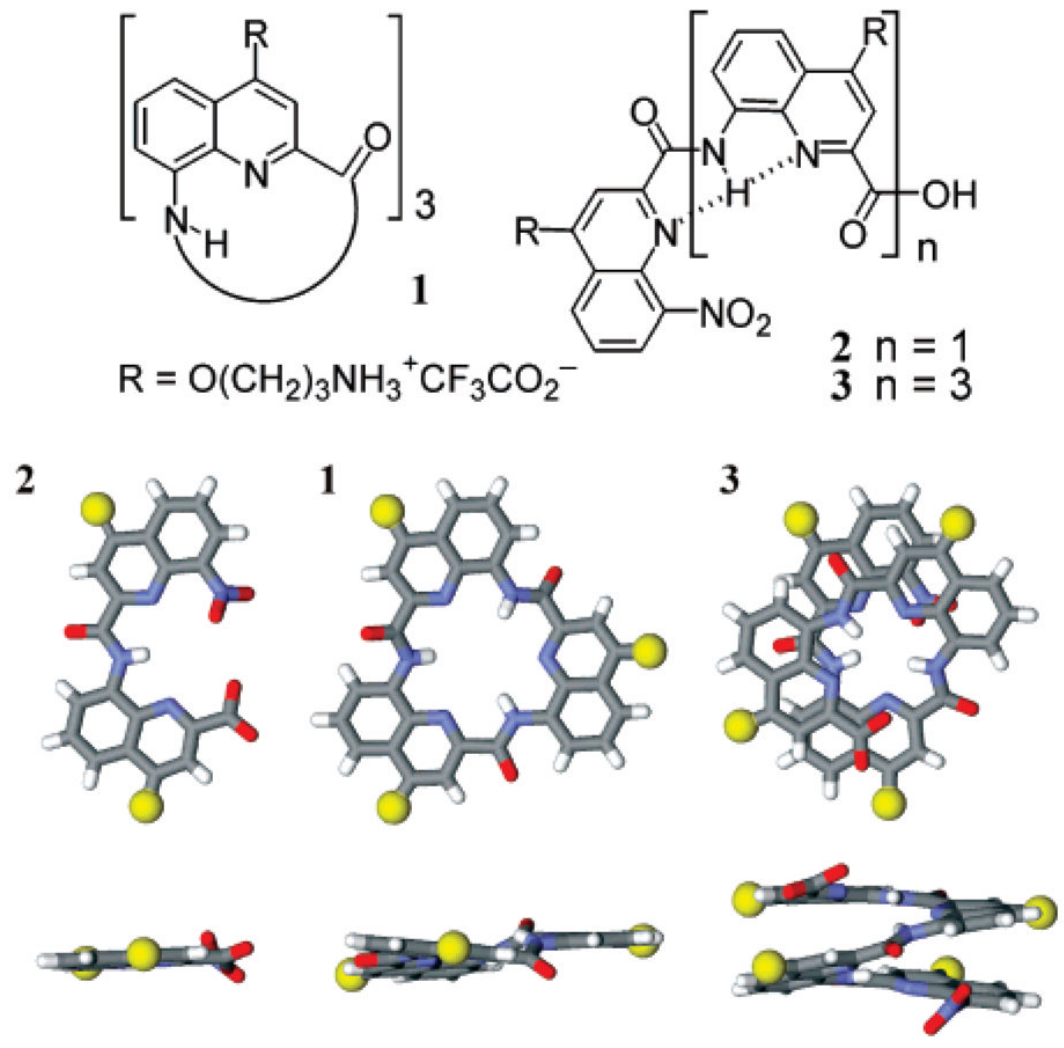

Figure 1.

Formulas of cationic oligomers 1-3, top view and side view of models of their conformation based on crystal structures of lipophilic analogues.13,14 Side chains have been replaced by yellow spheres. 

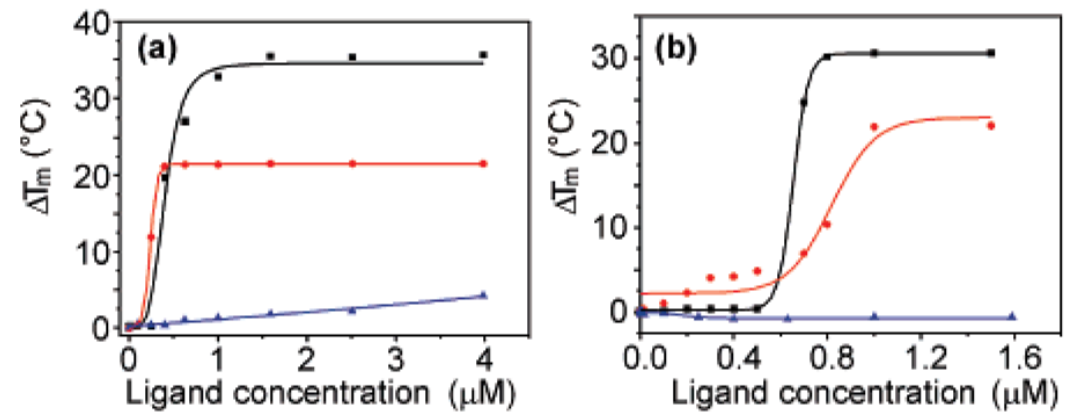

Figure 2.

FRET stabilization curves for macrocycle 1 (a) and telomestatin (b) upon binding to h-telo (black square), c-kit (red circle), and double-stranded DNA (blue triangle). 


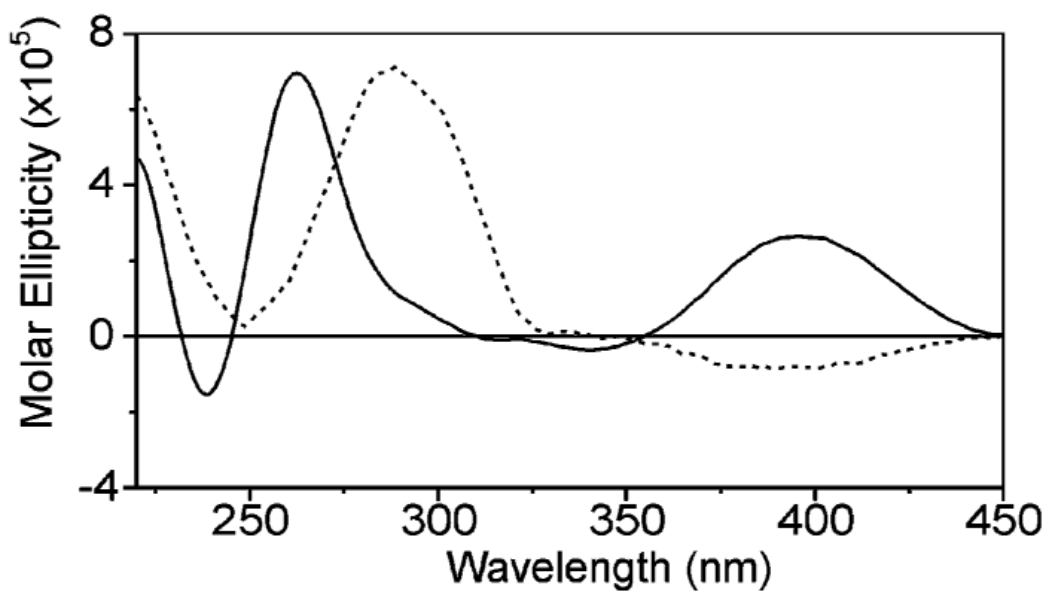

Figure 3.

CD spectra of a $12.5 \mu \mathrm{M}$ solution of h-telo $\mathrm{d}\left[\mathrm{A}\left(\mathrm{G}_{3} \mathrm{~T}_{2} \mathrm{~A}\right)_{3} \mathrm{G}_{3} \mathrm{~T}\right]$ in Tris buffer $(\mathrm{pH} 7.4), 3$ equiv of helical oligomer $\mathbf{3}$, and in the absence of salt (solid line) or in the presence of 100 $\mathrm{mM} \mathrm{K}^{+}$(dashed line). The salt induces conformational changes in the quadruplex (240-300 $\mathrm{nm}$ region) which in turn induces a different handedness in 3 (350-450 region). The 240300 region is essentially unchanged when $\mathbf{3}$ is absent (not shown). 


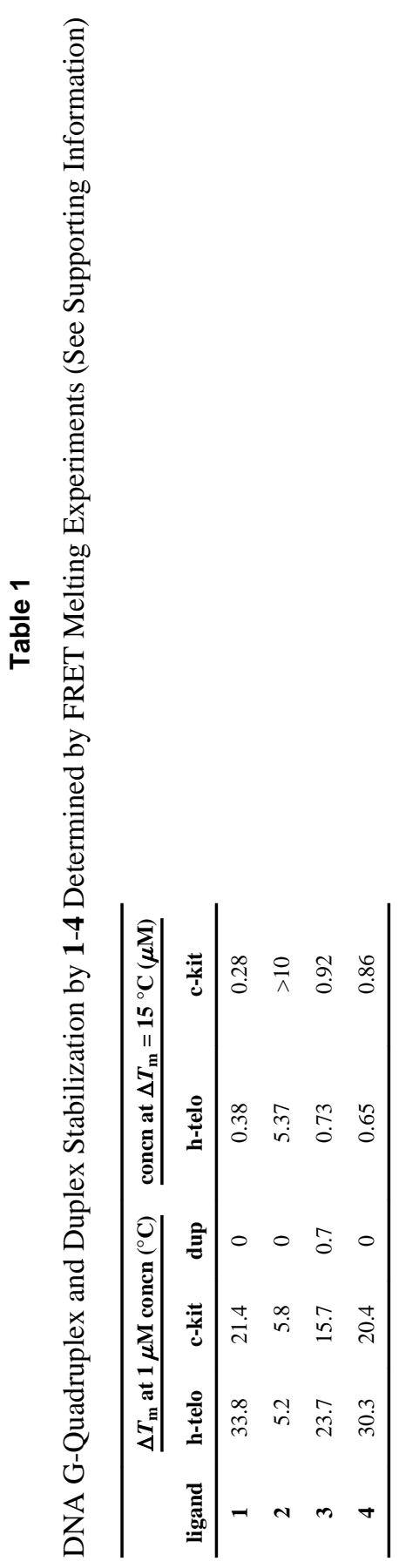

J Am Chem Soc. Author manuscript; available in PMC 2008 January 14. 